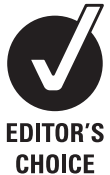

CHOICE
- An additional material is published online only. To view this file please visit the journal online (http://thorax.bmj.com/ content/67/8.toc)

${ }^{1}$ Respiratory Medicine Research Unit, Katholieke Universiteit Leuven, Leuven, Belgium ${ }^{2}$ Center of Molecular and Vascular Biology, Katholieke Universiteit Leuven, Leuven, Belgium

\section{Correspondence to}

Dr Wim Janssens, Laboratory of Pneumology, Respiratory Medicine, University of Leuven, Onderwijs en Navorsing 1 bus 706, Herestraat 49, Leuven 3000, Belgium; wim.janssens@ med.kuleuven.be

Received 26 June 2011 Accepted 29 February 2012 Published Online First 22 March 2012

\title{
Antielastin B-cell and T-cell immunity in patients with chronic obstructive pulmonary disease
}

\author{
Manuela Rinaldi, ${ }^{1}$ An Lehouck, ${ }^{1}$ Nele Heulens, ${ }^{1}$ Renaud Lavend'Homme, ${ }^{2}$ \\ Vincent Carlier, ${ }^{2}$ Jean-Marie Saint-Remy, ${ }^{2}$ Marc Decramer, ${ }^{1}$ \\ Ghislaine Gayan-Ramirez, ${ }^{1}$ Wim Janssens ${ }^{1}$
}

\section{ABSTRACT}

Rationale Antielastin autoimmunity has been hypothesised to drive disease progression in chronic obstructive pulmonary disease (COPD). The proposed mechanism is currently disputed by conflicting data. The authors aimed to explore antibody responses against elastin in a large and extensively characterised COPD population and to assess elastin-specific peripheral T-cell reactivity in a representative subgroup.

Methods Antielastin antibodies were analysed with indirect ELISA on the plasma of 320 patients with COPD (Global Initiative for Chronic Obstructive Lung Disease $1-4)$ and 143 smoking controls. In a second group of 40 patients with COPD and smoking controls, T-cell responses against extracellular matrix (elastin, collagen I and collagen V) were determined with enzyme-linked immunosorbent spot (EliSpot) (interferon $\gamma$ (IFN $\gamma$ ) and interleukin-2) on peripheral blood mononuclear cells and compared with the responses of 11 never-smoking controls.

Results Antielastin antibody titres were not elevated in patients with COPD compared with smoking controls and even decreased significantly with increasing severity of COPD $(p<0.001)$. Lower antielastin antibody titres were also found in a subgroup of patients with CT-proven emphysema. Elastin-specific INF $\gamma$-mediated T helper 1 responses could not be revealed in smoking subjects with and without COPD. Collagen I-mediated T-cell responses were also absent, which contrasted with a significant increased anticollagen $\mathrm{V}$ response in the smoking controls and patients with COPD compared with the never smokers $(p=0.008)$. Collagen V-mediated T-cell responses could not discriminate between patients with COPD and smoking controls.

Conclusion A systemic immune response against elastin could not be identified in patients with COPD. By contrast, collagen V-mediated autoimmunity was increased in the subgroup of smokers and may potentially contribute to the pathogenesis of COPD.

\section{INTRODUCTION}

Chronic obstructive pulmonary disease (COPD) is characterised by an abnormal inflammatory response in the airways and lung parenchyma to the inhalation of toxic or noxious particles. This inflammatory response progressively increases with severity of disease. Although several factors may contribute to COPD, cigarette smoke represents the major risk factor for COPD. Remarkably, inflammation in the lungs persists for years after smoking

\section{Key messages}

What is the key question?

- Is chronic obstructive pulmonary disease (COPD) characterised by a peripheral immune response against elastin?

What is the bottom line?

- Lung destruction in COPD may lead to the release of self-antigens.

- This study investigated whether elastin and other components of the extracellular matrix are inducing a T-cell and B-cell immune response, which may be specific for COPD.

Why read on?

- Our study shows that a systemic immune response against elastin fragments was not present in patients with COPD.

- However, smoke-induced T-cell immunity against collagen $\mathrm{V}$ was found to be more prevalent in smokers and needs further attention.

cessation and the precise nature of this complex immune response remains unclear. ${ }^{1-3}$ Historically, the pathogenesis of COPD has been approached as a disturbed innate immune response of epithelial cells, neutrophils and macrophages. ${ }^{4}{ }^{5}$ However, several pieces of evidence are currently pointing towards an important role of the adaptive immune system. The increasing presence of CD8 cells, CD4 cells and $B$ cells in the small airways and lung tissue of patients with more severe disease ${ }^{6-8}$ their oligoclonal aspect, ${ }^{89}$ and their structural organisation as tertiary lymphoid tissue ${ }^{10}$ indicate that antigen-specific stimuli elicit an immune reaction, potentially enhancing the ongoing inflammation. At present, the nature of the antigens towards which the immune response might be directed remains unclear. ${ }^{13}$

There are several hypotheses which describe apoptotic epithelial cells, apoptotic endothelial cells, microbial peptides or components of the extracellular matrix (elastin and collagen) as potential antigens. Supporting evidence comes from the presence of antinuclear antibodies ${ }^{11}$ and circulating IgG antibodies against pulmonary epithelial cells, ${ }^{12}$ endothelial cells ${ }^{13}$ and extracellular matrix proteins ${ }^{14}$ in patients with COPD 
However, it remains unclear whether these antibodies should be regarded as bystander, protective or pathogenic antibodies as they may be equally found in healthy smokers. Besides, autoimmunity does not require self-antibodies per se whereas an underlying antigen-specific T-cell response is known to be key for developing autoimmunity. In this regard Lee and colleagues ${ }^{14}$ were the first to describe an autoimmune component in COPD by showing the presence of antielastin antibodies and reactive $\mathrm{T}$ cells against elastin peptides in peripheral blood of patients with severe COPD. However, other studies investigating antielastin antibodies in plasma/serum samples failed to detect any differences in antielastin antibody levels between controls and patients with COPD. ${ }^{15-17}$ Some of these studies were hampered by small sample size, others focused on an $\alpha-1$ antitrypsin deficient population. As none of these studies explored the relationship with centrilobular emphysema or looked at elastinspecific T-cell responses, the role of antielastin autoimmunity is still debated.

Immunity against collagen type I, the other major source of the extracellular lung matrix, has also been explored in COPD, all with negative results. ${ }^{14-17}$ Interestingly, collagen type $\mathrm{V}$ has recently been proposed as auto-antigen in a variety of other chronic diseases including respiratory diseases. ${ }^{18-21}$ Collagen $\mathrm{V}$ is a minor component of the extracellular matrix abundant in lung, skin and placenta, which may, as a result of injury, become immunogenic. Recent studies have demonstrated that interleukin (IL)-17-dependent cellular autoimmunity against collagen $\mathrm{V}$ was present in patients with bronchiolitis obliterans syndrome (BOS), a clinical/pathological description for chronic rejection originating from the small airways. ${ }^{18} 22$ More specifically, Tiriveedhi et al showed that with the release of matrix metalloproteinases (MMP-9, MMP-2), different cryptic epitopes of collagen $\mathrm{V}$ become uncovered, driving $\mathrm{T}$ cells into a $\mathrm{T}$ helper 1 (Th1)/Th17 phenotype resulting in $\mathrm{BOS}^{23}$ So far, no studies have explored collagen type $\mathrm{V}$ as a potential source of antigen in COPD, but given the presence and pathogenic role of MMPs and Th17 cells in the peripheral airways of patients with COPD, it may sound attractive. ${ }^{24-26}$

Since conflicting results were obtained for antielastin immunity in COPD, the present study aimed to determine antielastin antibodies in a large COPD population with different stages of severity. In a second sample, we also explored T-cell responses against elastin and compared this with $\mathrm{T}$-cell reactivity against other relevant compounds of the extracellular matrix (collagen I and collagen $\mathrm{V}$ ).

\section{MATERIALS AND METHODS \\ Study population}

Study participants were selected at the University Hospital of Leuven. The first study population consisted of patients with clinical COPD who were recruited at the outpatient clinic, and patients with subclinical COPD (Global Initiative for Chronic Obstructive Lung Disease (GOLD) stage 1) or smoking controls who were obtained from the Nelson study, a CT screening study for early detection of lung cancer in (ex)-smokers. ${ }^{27}$ All subjects had a minimal age of 50 years, a smoking history of $\geq 30$ packyears and were stable at time of inclusion. COPD diagnosis was based on GOLD criteria (post bronchodilator ratio forced expiratory volume in $1 \mathrm{~s}\left(\mathrm{FEV}_{1}\right) /$ forced vital capacity $\left.<0.7\right) .{ }^{28}$ The presence of emphysema was determined by CT scan of the chest as assessed by two independent radiologists. All 463 subjects provided a plasma sample and a representative subgroup of 25 patients with COPD was selected for a second blood sampling to assess for between-test variability in one subject. For enzymelinked immunosorbent spot (EliSpot) experiments, a second smaller cohort was recruited at the same hospital and consisted of 28 patients with COPD and 12 smoking controls who were compared with 11 never-smoking healthy subjects selected by age and gender from relatives of patients or hospital personnel. The project was approved by the ethical committee of UZ Leuven and all subjects gave informed consent.

\section{Antielastin and anticollagen $\mathbf{V}$ antibodies}

Antielastin antibody levels were determined in duplicate on plasma samples of the cohort of 463 subjects and on the second group of 51 subjects. To determine antielastin antibody levels, an ELISA was used, according to the protocol of Lee et al ${ }^{14}$ with the following changes. Human plasma samples were diluted with a twofold serial dilution starting from 1:40 to 1:1280. A goat antihuman horseradish peroxidase (HRP) conjugated IgG (Ab6759, Abcam, Cambridge, UK) was used as secondary antibody $(4 \mu \mathrm{g} / \mathrm{ml})$ in our assay. The optical density of individual wells was determined at $450 \mathrm{~nm}$ using a standard microplate spectrophotometer. In our assay, we selected as a positive control a plasma sample of a patient with scleroderma with known positive titres of antielastin antibodies. The samples were calculated relative to the standard positive control and values were expressed as relative units: (OD sample/OD positive control $) \times 100$. In a subgroup of 25 patients with COPD from the first cohort, antielastin antibody titres were repeated to determine variability over time. The average time between two samples was 2.61 years. In the second cohort of 51 individuals, anticollagen $\mathrm{V}$ antibody titres were also quantified by ELISA. A more detailed protocol can be found in the online supplement.

\section{Isolation of peripheral blood mononuclear cells}

In the second group consisting of 28 patients with COPD, 12 smoking controls and 11 healthy non-smoking controls, fresh blood samples were collected to isolate peripheral blood mononuclear cells (PBMCs) by density gradient centrifugation. Blood samples were diluted with PBS (Dulbecco's phosphate buffer saline, Invitrogen, Merelbeke, Belgium) and placed on Ficoll gradient (Lymphoprep, Axis-Shield, Oslo, Norway). Samples were centrifuged for $20 \mathrm{~min}$ at $600 \times \mathrm{g}$. After centrifugation, the mononuclear layer was isolated and cells were washed twice with PBS at $300 \times \mathrm{g}$ for $10 \mathrm{~min}$. To determine total cell counts of mononuclear cells, trypan blue solution (Sigma Aldrich, Bornem, Belgium) was used. A median number of $30 \times 10^{6}$ PBMCs per patient were harvested. Cells were diluted in freezing medium (10\% dimethylsulfoxide (DMSO), 45\% fetal bovine serum (FBS) and $45 \%$ rpmi-Glutamax medium) and aliquots of $10 \times 10^{6}$ cells $/ \mathrm{ml}$ were frozen at $-80^{\circ} \mathrm{C}$ prior to EliSpot.

\section{EliSpot assay}

The EliSpot assay was performed on PBMCs to determine T-cell differentiation in response to antigen. Human lung elastin peptides (OP45, Elastin Products Company, Owensville, Missouri, USA), human collagen V (C3657, collagen V from human placenta, Sigma Aldrich) and human collagen I peptides (CH783, Elastin Products Company) were used. EliSpot kits for interleukins interferon $\gamma$ (INF $\gamma$ ), IL-2 and IL-17 (Gen-Probe Diaclone, Sanquin, Amsterdam, The Netherlands) were purchased and EliSpots were performed according to the product guidelines. Briefly, high-protein binding microtitre plates (Multiscreen filter plates, Millipore, Brussels, Belgium) were incubated with $100 \mu \mathrm{l}$ of diluted capture antibody at $4^{\circ} \mathrm{C}$ overnight. Plates were blocked with media (Rpmi 1640 +Glutamax, 
Invitrogen) containing 10\% FBS (Invitrogen, Merelbeke) for INF $\gamma$ and IL-17 or $1 \%$ Bovine serum albumin (BSA) for IL-2. For each patient, $250000 \mathrm{PBMCs} /$ well were cultured in triplicate in the presence of $10 \mu \mathrm{g} / \mathrm{ml}$ elastin, collagen I or collagen $\mathrm{V}$ peptides for $15-20 \mathrm{~h}$ at $37^{\circ} \mathrm{C}$. Tetanus toxoid (gift from Center of Molecular and Vascular Biology, KU Leuven, Belgium) or pokeweed (L8777, Lectin from Phytolacca americana, Sigma Aldrich) and culture medium (rpmi 1640 + Glutamax) were used as positive and negative controls. After several washing steps, detection antibody was applied for $1 \mathrm{~h}$ and $30 \mathrm{~min}$ at room temperature prior to the addition of streptavidin-alkaline phosphatase conjugate for $1 \mathrm{~h}$. After washing, colour development substrate was added to the wells for 5-20 min until spot formation was visualised, a reaction which was then stopped by distilled water. Coloured spots were counted with an EliSpot reader and analysed as the mean of triplicate conditions. Results are expressed as the signal intensity of peptide conditions relative to the background (ratio) in the samples with reactive positive control conditions (45/51). Four patients with COPD and two smoking controls were excluded due to low reactivity against the positive control. To determine the percentage of positive samples, a cutoff value was set on the mean+1.96 SD of the healthy non-smoking control group. Samples with titres above this cutoff value were labelled as reactive.

\section{Statistical analyses}

All statistical analyses were performed with Graph Pad Prism (version 4.1) or with SAS (version 9.1). To determine if values were normally distributed, the D'Agostino and Pearson normality test was performed. Variables were expressed as mean $\pm S D$, proportions, or when showing a non-parametric distribution, as median $\pm I O R$. To determine differences between groups, a Mann-Whitney test or Kruskall-Wallis test was used. The Fisher exact test was used for frequency variables. Spearman's rank correlation was performed to determine associations. Relationships between antibody titres and $\mathrm{FEV}_{1}, \mathrm{COPD}$ or emphysema presence were adjusted for age and smoking status via multiple linear regression analysis and reported as estimates with $95 \%$ CI. Changes of antibody titres over time in one patient were assessed by Wilcoxon signed rank test. For all tests, $\mathrm{p}$ values $<0.05$ were considered as statistically significant.

\section{RESULTS \\ Study population 1}

\section{Baseline characteristics}

The characteristics of the studied population are shown in table 1. Of 463 subjects, 320 were classified as having COPD (GOLD 1-4) whereas 143 were classified as controls. Groups were matched for gender and current smoking status but controls were slightly younger and had less pack-years compared with the COPD group $(p<0.001)$. As expected, patients with COPD had lower body weight and reduced pulmonary function. Based on a CT scan of the chest, emphysema was identified in $70 \%$ of the COPD population compared with $6 \%$ of the smoking controls $(p<0.001)$.

\section{Antielastin antibody levels}

Median antielastin antibody titres were not increased in patients with COPD compared with smoking controls (figure 1A). When classifying according to GOLD stages, antielastin antibody titres were even decreased in GOLD stage 3 and GOLD stage 4 compared with smoking controls $(p=0.004)$ (figure $1 B)$. Similarly, when stratifying for CT-proven emphysema, lower antielastin antibody titres were also found in subjects with

Table 1 Baseline characteristics of the subjects

\begin{tabular}{|c|c|c|c|}
\hline & Smoking controls & COPD & p Value \\
\hline No of subjects & 143 & 320 & \\
\hline Age (years) & $61(58-65)$ & $65(60-720)$ & $<0.001$ \\
\hline Body mass index & $27(24-29)$ & $25(22-28)$ & $<0.001$ \\
\hline \multicolumn{4}{|l|}{ Sex } \\
\hline Men (\%) & $109(76)$ & $252(79)$ & 0.55 \\
\hline Women (\%) & $34(24)$ & $68(21)$ & \\
\hline \multicolumn{4}{|l|}{ Smoking history } \\
\hline Pack-years & $39(30-53)$ & $46(33-61)$ & 0.002 \\
\hline \multicolumn{4}{|l|}{ Smoking status } \\
\hline Current smokers (\%) & $81(57)$ & $179(56)$ & \\
\hline $\mathrm{FEV}_{1}$ (litres) & $3.1(2.6-3.6)$ & $1.4(0.96-2.23)$ & $<0.001$ \\
\hline $\mathrm{FEV}_{1}$ (\% predicted) & $102(94-111)$ & $53(36-76)$ & $<0.001$ \\
\hline FVC (litres) & $4.2(3.4-4.8)$ & $3.2(2.4-3.9)$ & $<0.001$ \\
\hline $\mathrm{FEV}_{1} / \mathrm{FVC}$ & $0.75(0.73-0.79)$ & $0.48(0.37-0.62)$ & $<0.001$ \\
\hline GOLD stages & & $1-4$ & \\
\hline GOLD $1(\%)$ & & $72(23)$ & \\
\hline GOLD $2(\%)$ & & $97(30)$ & \\
\hline GOLD $3(\%)$ & & $92(29)$ & \\
\hline GOLD $4(\%)$ & & $59(18)$ & \\
\hline \multicolumn{4}{|l|}{ Emphysema } \\
\hline CT evidence (\%) & $8(6)$ & $224(70)$ & $<0.001$ \\
\hline No CT evidence (\%) & $134(94)$ & $96(30)$ & \\
\hline CT unavailable (\%) & $1(0)$ & $0(0)$ & \\
\hline Median elastin antibodies (relative units) & $52(34-67)$ & $40(27-61)$ & 0.001 \\
\hline
\end{tabular}

Parameters are expressed as median with IQR. Sex, smoking status, GOLD stages and the presence of emphysema are expressed as percentages. Mann-Whitney or Fisher exact $p$ values are reported.

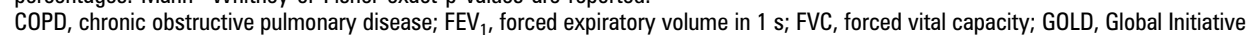
for Chronic Obstructive Lung Disease. 

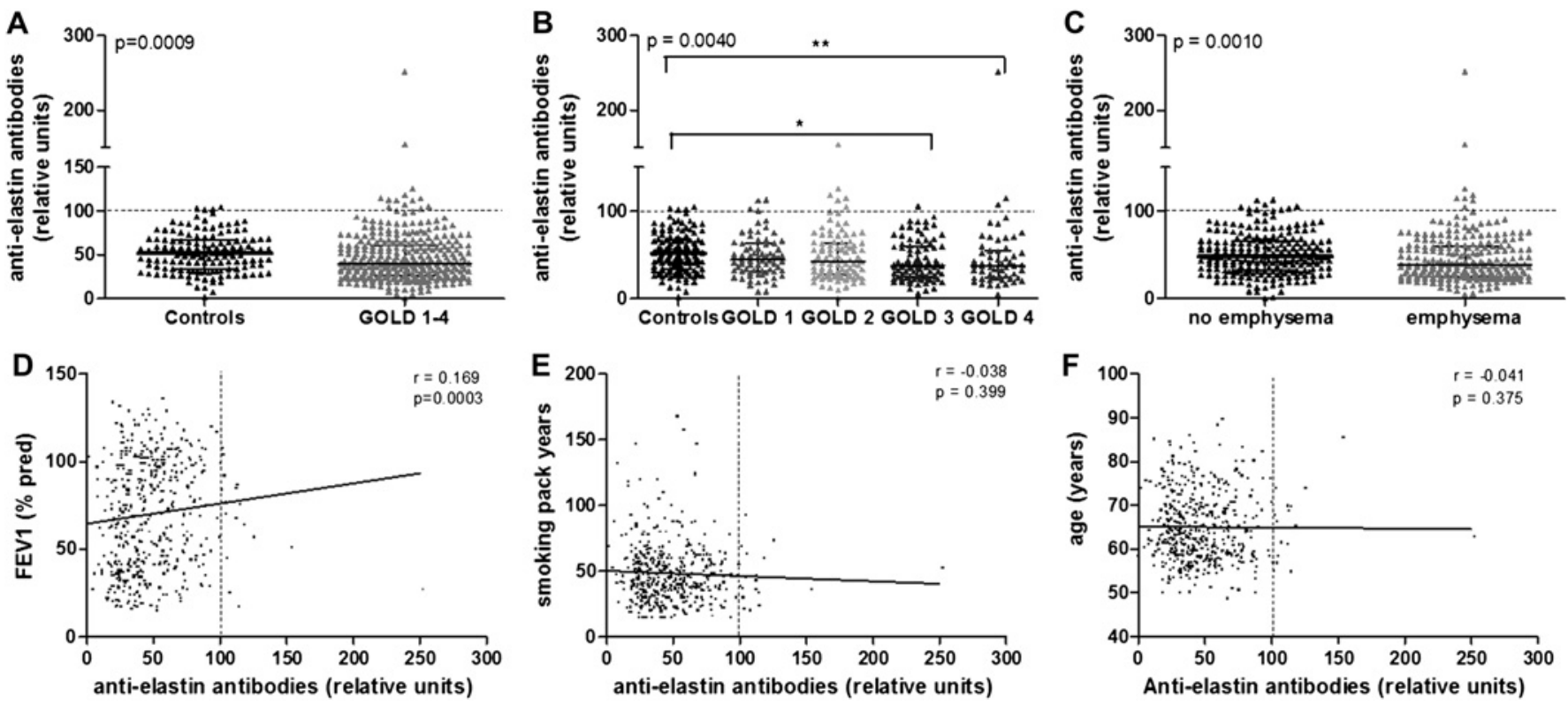

Figure 1 Median antielastin antibody titres in plasma samples of population 1 ( $n=463$ ). A. Antielastin antibody levels of chronic obstructive pulmonary disease (COPD) and smoking control group. B. Antielastin antibody titres of smoking controls and patients with COPD according to different Global Initiative for Chronic Obstructive Lung Disease (GOLD) classes. C. Antielastin antibody titres between patients with and without emphysema. D. Scatterplot of antielastin antibody titres and forced expiratory volume in $1 \mathrm{~s}\left(\mathrm{FEV}_{1}\right)(\%$ predicted). E. Scatterplot of antielastin antibody titres and smoking pack-years. F. Scatterplot of antielastin antibody titres and age. In panels $A-C$, data are presented as median $\pm I Q R$. ${ }^{*} p<0.05,{ }^{* *} p<0.01$. A cutoff line is marked at relative units equal to $100 \%$.

emphysema compared with subjects with no emphysema on CT (figure 1C). There was a weak correlation between antielastin antibody levels and $\mathrm{FEV}_{1}$ expressed as percentage predicted $(\mathrm{r}=0.169, \mathrm{p}<0.001)$, which persisted after adjustment for number of pack-years and age with multiple regression analysis $(\beta=0.09$ (0.01-0.16), $p=0.035)$ (figure $1 \mathrm{D})$. Overall, antielastin antibody titres were very low. Only $4 \%$ of the subjects had antibody titres equal to or higher than the control patient with scleroderma, with similar prevalences in the COPD (4.38\%) and emphysema (2.50\%) groups compared with their respective smoking control groups $(2.80 \%$ and $0 \%)$. In a representative group of 25 patients with COPD, antielastin antibody levels were reassessed on a second blood sample. Although mean levels were not significantly different $(p=0.89)$, $48 \%$ of patients had reduced levels and $52 \%$ increased values over a median time interval of 2.61 years $(2.40-2.83)$. Two out of three patients who had positive titres on the first measurement had an important reduction in antibody levels towards negative values of $25 \%$ from the positive control (figure 2 ).

\section{Study population 2}

\section{Baseline characteristics}

In a second group of 51 subjects, a larger blood sample was taken to explore peripheral T-cell responses of patients with COPD and smoking subjects in comparison with the responses of healthy never smoking controls $(n=11)$. Baseline characteristics are shown in table 2. Among patients with COPD, four patients were classified in GOLD I (14\%), nine patients in GOLD II $(32 \%)$, nine patients in GOLD III (32\%) and six patients in GOLD IV (22\%). Based on a CT scan of the chest, emphysema was identified in $68 \%$ of patients with COPD compared with $8 \%$ of the smoking controls. Median titres of antielastin and anticollagen $\mathrm{V}$ antibodies of the different groups were not statistically different.
T-cell reactivity against components of extracellular matrix

Median elastin-specific Th1 responses (IFN $\gamma$ ) and collagen I-specific Th1 responses (IFN $\gamma$ ) were not statistical significantly different between patients with COPD, smoking and nonsmoking controls. However, median collagen V-specific Th1 immune responses (IFN $\gamma$ ) were found to be significantly higher in the smoking controls and patients with COPD compared with the never smoking subjects $(p=0.008)$, with no difference between smoking controls and patients with COPD (table 3). In addition, positive samples were identified in a higher proportion of smoking subjects and patients with COPD (14/34) compared with non-smoking controls (1/11), although this finding did not reach the level of statistical significance $(p=0.066)$. When differentiating smoking individuals on the presence of emphysema, again collagen $\mathrm{V}$ induced IFNy expression was not different between the groups (table 4). The EliSpot assay for IL-2 expression after antigen stimulation was less sensitive as no Th1 responses for IL-2 were found to be increased in any of the groups (data not shown). Similarly, Th17 responses remained below the detection limit since only a few spots in a limited number of subjects were measured in the positive control with pokeweed. These data are not reported.

\section{DISCUSSION}

This study investigates the potential presence of an autoimmune response against different components of the extracellular matrix in COPD. Our main findings are that antielastin antibody titres were not increased in a large COPD population compared with smoking controls and that peripheral T-cell responses against elastin could not be revealed in a representative sample of patients. Although our data contrast with the findings of Lee et $\mathrm{al}^{14}$ showing increased antibody titres and Th1 responses against elastin in patients with severe COPD, the present study corroborates with several recent publications not 


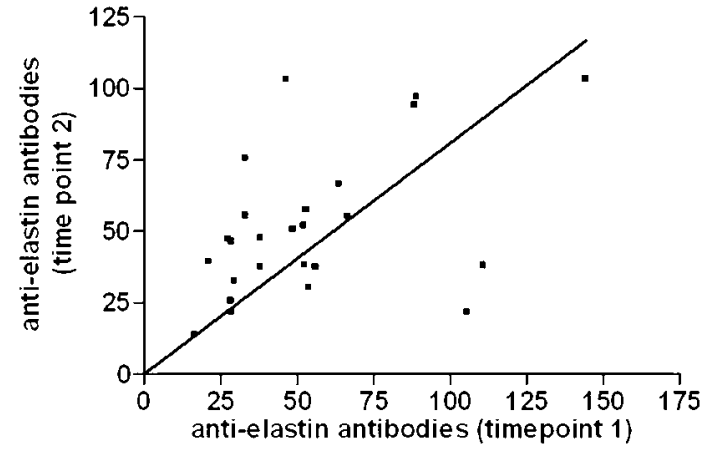

Figure 2 Scatterplot of the chronic obstructive pulmonary disease subpopulation $(n=25)$ showing the correlation between antielastin antibody titres measured at two different time points in one subject.

being able to confirm antielastin autoimmunity in COPD. Collagen V-specific autoimmunity by contrast seems to be associated with smoking history and may eventually be involved in the pathogenesis of COPD.

Since most of the studies on antielastin antibodies may be criticised on methodology, ${ }^{15}$ use of a non-smoking control group, ${ }^{17}$ or focus on a particular phenotype of $\alpha-1$ antitrypsin deficiency, ${ }^{16}$ our data may redirect the ongoing debate. Indeed, similar to the study of Lee and colleagues, ${ }^{14}$ we applied a proper standard control on each of the ELISA plates and expressed antibody titres relative to this positive control. We used a much larger COPD population of 320 subjects representing different stages of severity and compared them with a smoking control population of 143 subjects, nearly matched for gender, age and smoking status. In addition to bronchial obstruction and $\mathrm{FEV}_{1}$, we also explored relationships with CT-proven emphysema as antielastin immunity may potentially target the parenchyma to a greater extent. Despite these measures, no relationships between antibody titres, disease presence or severity could be observed. Moreover, when repeating antibody titres over time in a limited subgroup, median values were not different but large variability was observed in most subjects between paired samples. Two of the three samples with positive titres at the first measurement showed negative values at the second measurement, indicating that the use of antielastin antibody titres, even when positive, is highly variable and therefore not useful as a biomarker to appreciate auto-immunity. In fact, these findings are not surprising as it is well known that serum antibody levels are highly variable and do not form a prerequisite for autoimmunity, which often is only driven by auto-reactive $\mathrm{T}$ cells. We therefore assessed $\mathrm{T}$-cell reactivity against elastin on PBMCs in another sample and compared this reaction with the response of PBMCs against other lung matrix proteins. In contrast to the study of Lee and colleagues, ${ }^{14}$ elastin-specific Th1 responses (IFN $\gamma$ and IL-2) could not be revealed in our study. This may relate to a different sensitivity of the assay as we used EliSpot on whole PBMCs instead of cocultures of antigenpresenting cells enriched with purified $T$ cells. However, our assay was able to pick up a high elastin-specific response in one smoking control, and more importantly, the absence of elastinspecific Th1 responses was in strong contrast with our observation that collagen V-specific Th1 (IFN $\gamma$ ) responses could be detected in $41 \%$ of the smoking subjects. This indicates that the Elispot assay was able to pick up T-cell immune responses against self-antigens if sufficiently present.

The observed Th1 (IFN $\gamma$ ) response against lung-specific collagen $\mathrm{V}$ in patients with COPD and smoking subjects is intriguing. Recent studies have highlighted a potential role of collagen $\mathrm{V}$ as an auto-antigen in $\mathrm{BOS}^{18}$ and atherosclerosis. ${ }^{19}$ Both diseases may be characterised by persistent lung damage and inflammation through histocompatiblity mismatch or

Table 2 Baseline characteristics of the subpopulation

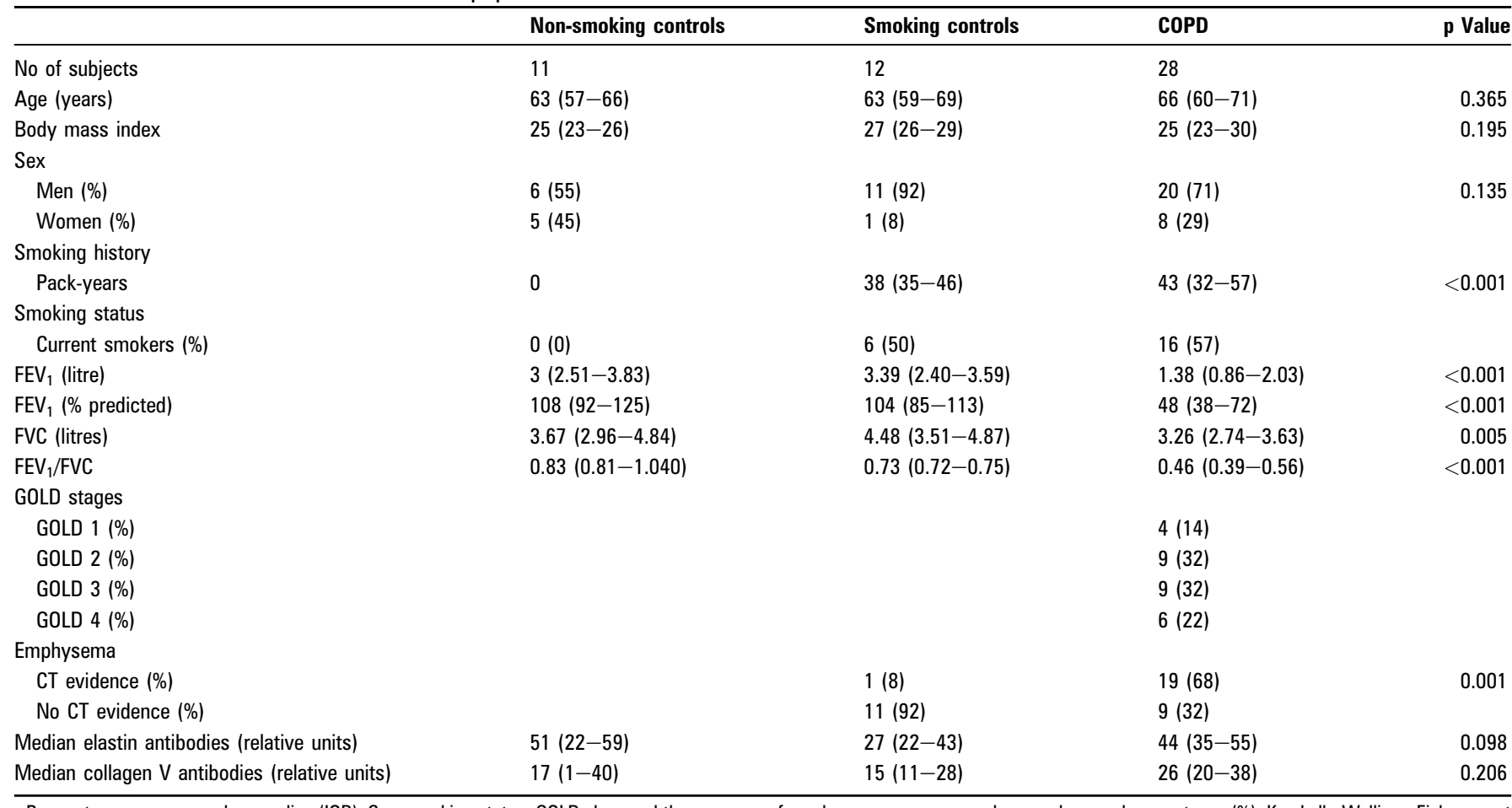

Parameters are expressed as median (IQR). Sex, smoking status, GOLD class and the presence of emphysema are expressed as numbers and percentages (\%). Kruskall-Wallis or Fisher exact $\mathrm{p}$ values are reported.

COPD, chronic obstructive pulmonary disease; $\mathrm{FEV}_{1}$, forced expiratory volume in $1 \mathrm{~s}$; FVC, forced vital capacity; GOLD, Global Initiative for Chronic Obstructive Lung Disease. 
Table 3 T-cell reactivity (IFN $\gamma$ and IL-2) on PMBCs of 45 subjects against elastin peptides, collagen I peptides and collagen $V$ peptides, stratified according to COPD status

\begin{tabular}{|c|c|c|c|c|}
\hline & $\begin{array}{l}\text { Non-smoking } \\
\text { controls }\end{array}$ & $\begin{array}{l}\text { Smoking } \\
\text { controls }\end{array}$ & COPD & p Value \\
\hline No. of subjects & 11 & 10 & 24 & \\
\hline \multicolumn{5}{|l|}{ Elastin peptides } \\
\hline $\begin{array}{l}\text { IFN } \gamma \text { expression } \\
\text { (ratio) }\end{array}$ & $1.4(0.9-2.4)$ & $2.0(1.4-5.4)$ & $2.8(1.4-4.7)$ & 0.150 \\
\hline $\begin{array}{l}\text { IL-2 expression } \\
\text { (ratio) }\end{array}$ & $0.9(0.9-1.5)$ & $1.4(1.0-1.8)$ & $1.0(0.7-1.3)$ & 0.123 \\
\hline \multicolumn{5}{|l|}{ Collagen I peptides } \\
\hline $\begin{array}{l}\text { IFN } \gamma \text { expression } \\
\text { (ratio) }\end{array}$ & $1.3(0.9-1.9)$ & $1.4(1.0-2.6)$ & $2.1(0.9-3.3)$ & 0.478 \\
\hline $\begin{array}{l}\text { IL-2 expression } \\
\text { (ratio) }\end{array}$ & $1.2(0.6-1.4)$ & $1.0(0.8-1.9)$ & $1.0(0.7-1.3)$ & 0.637 \\
\hline \multicolumn{5}{|l|}{ Collagen V peptides } \\
\hline $\begin{array}{l}\text { IFN } \gamma \text { expression } \\
\text { (ratio) }\end{array}$ & $1.7(1.3-5.2)$ & $5.5(3.8-21.6)$ & $8.0(3.4-20.7)$ & $0.008 *$ \\
\hline $\begin{array}{l}\text { IL-2 expression } \\
\text { (ratio) }\end{array}$ & $0.7(0.6-1.1)$ & $1.2(0.9-1.7)$ & $1.1(0.8-1.6)$ & 0.164 \\
\hline
\end{tabular}

Data are presented as median (IOR). Kruskall-Wallis $p$ values are reported.

${ }^{*} \mathrm{p}<0.05$.

COPD, chronic obstructive pulmonary disease; IFN, interferon; IL, interleukin; PBMC, peripheral blood mononuclear cell.

smoking. Apart from antigen deliberation, smoking and inflammation are known to induce post-translational modifications of proteins, a process known to be associated with autoimmunity. ${ }^{1629}$ In line with this, Tiriveedhi et al found that with the presence of BOS a switch from downregulatory IL-10 responses to IFN $\gamma / \mathrm{IL}-17$ T-cell responses occurred, which corresponded to a change in immunodominant epitopes of collagen $\mathrm{V}$, most likely by increased release and activity of MMPs. ${ }^{23}$ A mixed Th1/Th17 immune response was also found in patients with atherosclerosis. ${ }^{19}$ Since the sensitivity of our assay for IL-17 was below the detection limit, we cannot speculate if a mixed Th1/Th17 immune response was present in our positive subjects. Similarly, it remains unclear to what extent collagen V T-cell responses may contribute to disease onset and progression in COPD, as they were equally found in the smoking group without COPD and there are no long-term clinical followup data available. We acknowledge that the relative low number

Table 4 T-cell reactivity (IFN $\gamma$ and IL-2) on PMBCs of 45 subjects against elastin peptides, collagen I peptides and collagen $\mathrm{V}$ peptides, stratified according to emphysema presence

\begin{tabular}{lllll}
\hline & $\begin{array}{l}\text { Non-smoking } \\
\text { controls }\end{array}$ & $\begin{array}{l}\text { Emphysema } \\
\text { absent }\end{array}$ & $\begin{array}{l}\text { Emphysema } \\
\text { present }\end{array}$ & p Value \\
\hline $\begin{array}{l}\text { No. of subjects } \\
\text { Elastin peptides }\end{array}$ & 11 & 15 & 19 & \\
$\begin{array}{l}\text { IFN } \gamma \text { expression } \\
\text { (ratio) }\end{array}$ & $1.4(0.9-2.4)$ & $3.0(1.5-5.2)$ & $2.6(1.3-4.5)$ & 0.116 \\
$\begin{array}{l}\text { IL-2 expression } \\
\text { (ratio) }\end{array}$ & $0.9(0.9-1.5)$ & $1.2(0.8-1.5)$ & $1.0(0.7-1.5)$ & 0.731 \\
$\begin{array}{l}\text { Collagen I peptides } \\
\text { IFN } \gamma \text { expression } \\
\text { (ratio) }\end{array}$ & $1.3(0.9-1.9)$ & $1.7(1.1-2.8)$ & $1.7(0.8-3.6)$ & 0.475 \\
$\begin{array}{l}\text { IL2 expression } \\
\text { (ratio) }\end{array}$ & $1.2(0.6-1.4)$ & $1.0(0.7-1.6)$ & $1.0(0.8-1.5)$ & 0.989 \\
$\begin{array}{l}\text { Collagen V peptides } \\
\text { IFN } \gamma \text { expression }\end{array}$ & $1.7(1.3-5.2)$ & $6.2(4.0-20.9)$ & $7.3(2.8-20.3)$ & $0.008^{*}$ \\
$\begin{array}{l}\text { (ratio) } \\
\text { IL-2 expression } \\
\text { (ratio) }\end{array}$ & $0.7(0.6-1.1)$ & $1.2(0.5-1.4)$ & $1.0(0.8-1.7)$ & 0.195 \\
\hline $\begin{array}{l}\text { Data are presented as median (IOR). Kruskall-Wallis } \mathrm{p} \text { values are reported. } \\
\text { * } \mathrm{p}<0.05 .\end{array}$ & & & \\
IFN, interferon; IL, interleukin; PBMC, peripheral blood mononuclear cell. & \\
\hline
\end{tabular}

of subjects may have confounded our findings, but given the emerging role of collagen $\mathrm{V}$ in related diseases, further research on this interesting pathway is warranted.

Our data should be carefully interpreted in terms of a contributing role for autoimmunity against elastin in COPD. Although we have shown that antielastin autoimmunity in the peripheral circulation is below the detection limit, we did not explore antigen specificity and clonal expansion of $\mathrm{B}$ and $\mathrm{T}$ cells residing in the lung. Even if we were able to detect elastinspecific $B$ and $T$ cells in lung tissue, the question of whether these cells enhance inflammation and catalyse disease progression is still not addressed. Recently, Brandsma et al ${ }^{30}$ demonstrated that immunisation with elastin peptides in chronically smoke-exposed mice did not aggravate emphysema. This may suggest that, at least in mice, elastin immune responses are not harmful to the lung or that immune tolerance quickly develops against such ubiquitous self-antigens to prevent further damage. At this stage, it is unclear whether immune tolerance against deliberated elastin fragments may explain the contradictory findings in humans. Overall, we conclude that a systemic immune response against elastin could not be detected in a large sample of patients with COPD. Smoke-induced T-cell immunity against collagen $\mathrm{V}$ was found to be rather prevalent and needs further attention.

Acknowledgements The authors would like to thank Erica Balligand and Kristien De Bent for collecting the blood samples.

Contributors MR participated in the study design, performed the experiments, data analysis and drafted the manuscript. AL and $\mathrm{NH}$ also performed part of the experiments. RL, VC and JMSR participated in the study design and were involved in revising the manuscript. MD, GGR and WJ conceived the study, participated in the study design and helped to draft the manuscript. All authors read and approved the final manuscript.

Funding The project was supported by the 'Fonds voor Wetenschappelijk Onderzoek Vlaanderen' (FWO-Flanders G.0687.09) and by AstraZeneca Pharmaceuticals. WJ is a clinical investigator of FWO-Flanders.

\section{Competing interests None.}

Patient consent The patients signed our consent form that was approved by the Ethical Committee, University Hospital of Leuven (UZ Leuven).

Ethical approval This study was conducted with the approval of the Ethical Committee, University Hospital of Leuven (UZ Leuven) and all patients gave informed consent.

Provenance and peer review Not commissioned; externally peer reviewed.

\section{REFERENCES}

1. Stefanska AM, Walsh PT. Chronic obstructive pulmonary disease: evidence for an autoimmune component. Cell Mol Immunol 2009;6:81-6.

2. Cosio MG, Majo J, Cosio MG. Inflammation of the airways and lung parenchyma in COPD: role of T cells. Chest 2002;121:160S-5S

3. Cosio MG, Saetta M, Agusti A. Immunologic aspects of chronic obstructive pulmonary disease. N Engl J Med 2009;360:2445-54.

4. D'hulst Al, Vermaelen KY, Brusselle GG, et al. Time course of cigarette smokeinduced pulmonary inflammation in mice. Eur Respir J 2005;26:204-13.

5. Hautamaki RD, Kobayashi DK, Senior RM, et al. Requirement for macrophage elastase for cigarette smoke-induced emphysema in mice. Science 1997;277:2002-4.

6. Hogg JC, Chu F, Utokaparch S, et al. The nature of small-airway obstruction in chronic obstructive pulmonary disease. N Engl J Med 2004;350:2645-53.

7. Saetta M, Baraldo S, Corbino L, et al. CD8+ cells in the lungs of smokers with chronic obstructive pulmonary disease. Am J Respir Crit Care Med 1999; 160:711-17.

8. van der Strate BW, Postma DS, Brandsma CA, et al. Cigarette smoke-induced emphysema: a role for the B cell? Am J Respir Crit Care Med. 2006:173:751-8.

9. Sullivan AK, Simonian PL, Falta MT, et al. Oligoclonal CD4+ T cells in the lungs of patients with severe emphysema. Am J Respir Crit Care Med 2005;172:590-6.

10. Brusselle GG, Demoor T, Bracke KR, et al. Lymphoid follicles in (very) severe COPD beneficial or harmful? Eur Respir J 2009;34:219-30.

11. Bonarius HP, Brandsma CA, Kerstjens HA, et al. Antinuclear autoantibodies are more prevalent in COPD in association with low body mass index but not with smoking history. Thorax 2011;66:101-7. 
12. Kuo YB, Chang CA, Wu YK, et al. Identification and clinical association of anticytokeratin 18 autoantibody in COPD. Immunol Lett 2010;128:131-6.

13. Feghali-Bostwick CA, Gadgil AS, Otterbein LE, et al. Autoantibodies in patients with chronic obstructive pulmonary disease. Am J Respir Crit Care Med 2008; 177:156-63.

14. Lee SH, Goswami S, Grudo A, et al. Antielastin autoimmunity in tobacco smokinginduced emphysema. Nat Med 2007;13:567-9.

15. Cottin V, Fabien N, Khouatra C, et al. Anti-elastin autoantibodies are not present in combined pulmonary fibrosis and emphysema. Eur Respir $J$ 2009;33:219-21.

16. Wood AM, de Pablo P, Buckley CD, et al. Smoke exposure as a determinant of autoantibody titre in alpha-antitrypsin deficiency and COPD. Eur Respir $\mathrm{J}$ 2011;37:32-8

17. Greene CM, Low TB, O’Neill SJ, et al. Anti-proline-glycine-proline or antielastin autoantibodies are not evident in chronic inflammatory lung disease. Am J Respir Crit Care Med 2010;181:31-5.

18. Burlingham WJ, Love RB, Jankowska-Gan E, et al. IL-17-dependent cellular immunity to collagen type $\mathrm{V}$ predisposes to obliterative bronchiolitis in human lung transplants. J Clin Invest 2007;117:3498-506.

19. Dart ML, Jankowska-Gan E, Huang G, et al. Interleukin-17-dependent autoimmunity to collagen type $V$ in atherosclerosis. Circ Res 2010:107:1106-16.

20. Velosa AP, Teodoro WR, de Oliveira CC, et al. Collagen V nasal tolerance in experimental model of systemic sclerosis. Arch Dermatol Res 2007;299:177-89.

21. Bharat A, Saini D, Steward N, et al. Antibodies to self-antigens predispose to primary lung allograft dysfunction and chronic rejection. Ann Thorac Surg 2010;90:1094-101.
22. Vanaudenaerde BM, Verleden SE, Vos R, et al. Innate and adaptive interleukin-17producing lymphocytes in chronic inflammatory lung disorders. Am J Respir Crit Care Med 2011;183:977-86.

23. Tiriveedhi V, Angaswamy N, Brand D, et al. A shift in the collagen $\mathrm{V}$ antigenic epitope leads to $T$ helper phenotype switch and immune response to self-antigen leading to chronic lung allograft rejection. Clin Exp Immunol 2012;167:158-68.

24. Russell RE, Culpitt SV, DeMatos C, et al. Release and activity of matrix metalloproteinase- 9 and tissue inhibitor of metalloproteinase- 1 by alveolar macrophages from patients with chronic obstructive pulmonary disease. Am J Respir Cell Mol Biol 2002;26:602-9.

25. Brusselle GG, Joos GF, Bracke KR. New insights into the immunology of chronic obstructive pulmonary disease. Lancet 2011:378:1015-26.

26. Hong SC, Lee SH. Role of th17 cell and autoimmunity in chronic obstructive pulmonary disease. Immune Netw 2010;10:109-14.

27. van Klaveren RJ, Oudkerk $M$, Prokop $M$, et al. Management of lung nodules detected by volume CT scanning. N Engl J Med 2009;361:2221-9.

28. Rabe KF, Hurd S, Anzueto A, et al. Global strategy for the diagnosis, management, and prevention of chronic obstructive pulmonary disease: GOLD executive summary. Am J Respir Crit Care Med 2007;176:532-55

29. Makrygiannakis D, Hermansson M, Ulfgren AK, et al. Smoking increases peptidylarginine deiminase 2 enzyme expression in human lungs and increases citrullination in BAL cells. Ann Rheum Dis 2008;67:1488-92.

30. Brandsma CA, Timens W, Geerlings $M$, et al. Induction of autoantibodies against lung matrix proteins and smoke-induced inflammation in mice. BMC Pulm Med 2010;10:64.

\section{DIFFERENTIAL DIAGNOSIS}

\section{Trustworthy guidance on your iPhone}
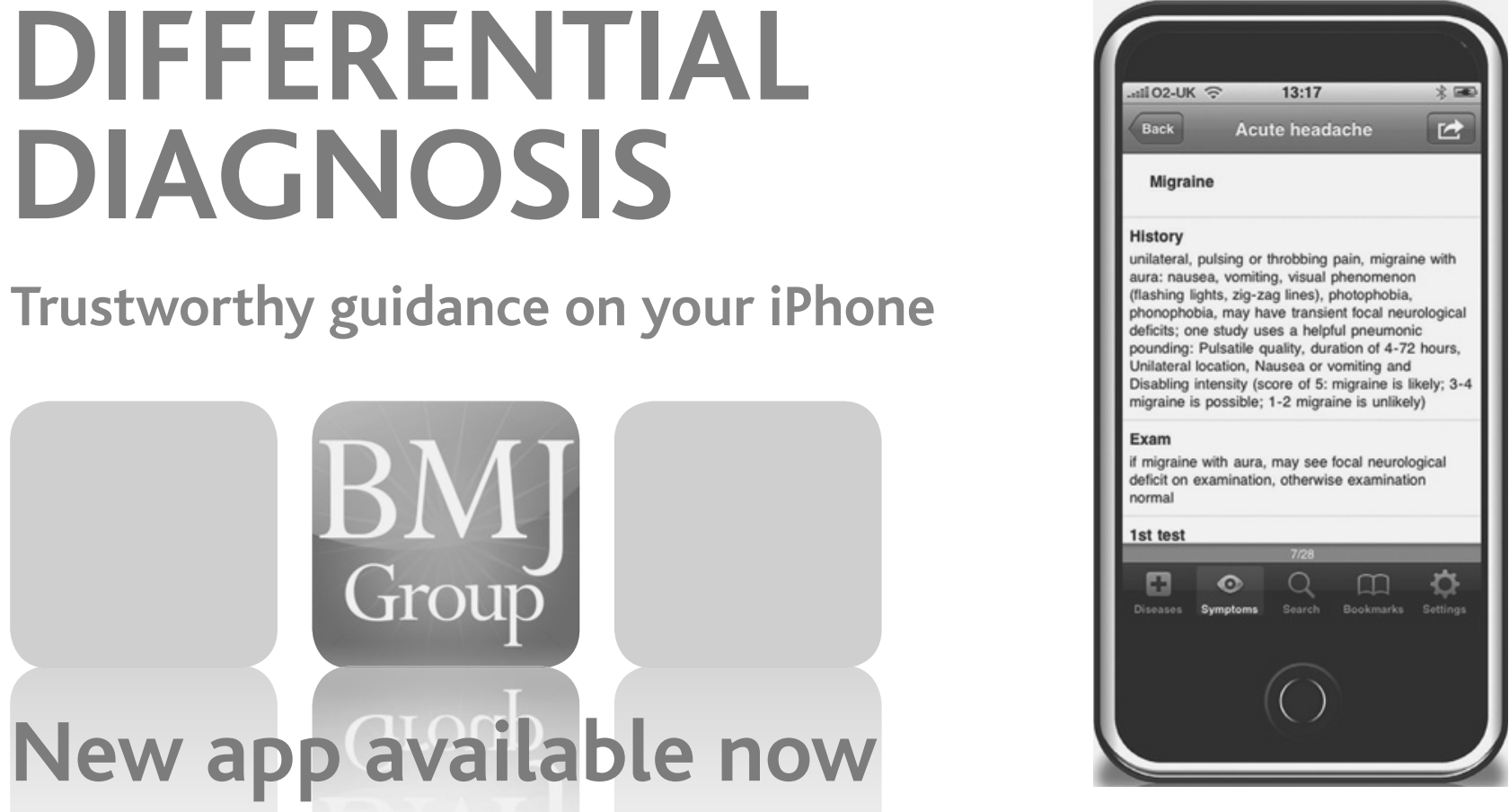

\section{Find out more at bestpractice.bmj.com/differentials}

